\title{
Transgenic potato plants expressing oxalate oxidase have in- creased resistance to oomycete and bacterial pathogens
}

\author{
M. SCHNEIDER ${ }^{* 1,2}$, E. DROZ ${ }^{3}$, PIA MALNOت̈ ${ }^{3}$, CATHERINE CHATOT $^{4}$, \\ E. BONNEL ${ }^{4}$ and J.-P. MÉTRAUX ${ }^{1}$
}

1 Département de Biologie-Biologie végétale, Université de Fribourg, ch. du musée 10, CH1700 Fribourg, Switzerland

2 Present address: Swiss Institute of Bioinformatics, Swiss-Prot, CMU, 1 Michel-Servet, CH1211 Geneva 4, Switzerland

3 Station fédérale de Changins (RAC), Route de Duillier, Case postale 254, CH-1260 Nyon, Switzerland

4 Germicopa, allée Loeiz Herrieu, F-29334 Quimper Cedex, France

* to whom correspondence should be addressed

Accepted for publication: 24 February 2003

Additional keywords: Phytophthora infestans, resistance, Streptomyces reticuliscabiei, oxalate oxidase, potato

\section{Summary}

Potato (cv. Bintje) was transformed with a gene encoding an oxalate oxidase from wheat under the control of the CaMV35S promoter. Transgenic potato plants produced high constitutive levels of $\mathrm{H}_{2} \mathrm{O}_{2}$ as visualized by 4-chloro-1-naphtol staining. The resistance of these plants was tested against Phytophthora infestans. An increased level of resistance to the disease was marked by a reduced number of lesions as well as by a decreased number of sporangia formed per lesion. In addition, oxalate oxidase overexpressing plants also exhibited improved resistance to Streptomyces reticuliscabiei, the causal agent of netted scab. Increased expression of oxalate oxidase had no effect on the interaction with Erwinia carotovora. These experiments show that overexpression of oxalate oxidase represents a potentially interesting approach for protection of potato to pathogens.

\section{Introduction}

Crop production is limited to various extents by plant diseases (Oerke \& Dehne, 1997). The losses caused by plant pathogens can be partly controlled by the use of resistant varieties, phytosanitary measures, biocontrol or pesticides. Research in the field of plant resistance mechanisms has been given increased attention during the last decades and some of the results have the potential for a possible application in crop protection (Lamb et al., 1992; Kuc, 2001). For example, $\mathrm{H}_{2} \mathrm{O}_{2}$ released by the plant during the early stages of pathogenesis has been shown to play a central role in plant defence (Levine et al., 1994). $\mathrm{H}_{2} \mathrm{O}_{2}$ was shown to have several effects that include direct anti-microbial effects, crosslinking of lignin precursors and proteins into the cell wall, as well as induction of defence-related genes in the plant (Brisson et 
al., 1994; Mehdy et al., 1996; Tenhaken et al., 1995). The effect of $\mathrm{H}_{2} \mathrm{O}_{2}$ on disease resistance has also been demonstrated in transgenic plants. For instance, potato plants expressing a fungal gene that encodes the protein glucose oxidase generate $\mathrm{H}_{2} \mathrm{O}_{2}$ and exhibit strong resistance to bacterial soft rot caused by Erwinia carotovora and to late blight caused by Phytophthora infestans (Wu et al., 1995, 1997).

In order to explore this further, we have transformed a susceptible potato variety with a gene from wheat encoding oxalate oxidase, an enzyme that catalyzes the formation of $\mathrm{H}_{2} \mathrm{O}_{2}$ from oxalate (Smirnoff \& Pallanca, 1996). Oxalic acid is produced by several fungal species, such as Penicillium, Sclerotinia, Aspergillus, Sclerotium and Rhizoctonia (Dutton \& Evans, 1996). Oxalate is also a plant metabolite derived from ascorbic acid (Smirnoff \& Pallanca, 1996). In this study, the effect of oxalate oxidase overexpression in potato was tested on an oomycete $(P$. infestans) and two bacterial ( $E$. carotovora and Streptomyces reticuliscabiei) pathogens of potato.

\section{Materials and methods}

Plant and growth conditions: Solanum tuberosum cv. Bintje and its transgenic derivatives, as well as cultivars Matilda or Charlotte were grown in pots in garden soil in growth chambers under the following conditions: $16 \mathrm{~h} / 8 \mathrm{~h}$ day/night period, $22^{\circ} \mathrm{C} /$ $17^{\circ} \mathrm{C}$ day/night temperatures, approximately $70 \% \mathrm{RH}$. All plants were propagated in vitro as previously described (Coquoz et al., 1995).

Gene constructs. The coding sequence from the oxalate oxidase gene gf- 2.8 (wheat germin; gift from B.G. Lane; (Lane et al., 1992, 1993) was inserted between the 35S promoter of cauliflower mosaic virus (Odell et al., 1985) and the nos terminator. A construct containing the promoter, the coding sequence and the terminator was inserted in the multicloning site of the binary vector $\mathrm{pBin} 19$ (Bevan, 1984). A detailed description of this construct, $\mathrm{pPH} 100$, and of the method used to transfer into Agrobacterium tumefaciens (strain LBA4404) (Ooms et a1., 1982) is given in Pignard et al. (1994).

Plant transformation. Internodes from in vitro grown potato plants (Solanum tuberosum cv. Bintje) were transformed using the Agrobacterium system according to Barker et al. (1993, 1994) and propagated from tissue cultures.

Determination of $\mathrm{H}_{2} \mathrm{O}_{2}$ production. The production of $\mathrm{H}_{2} \mathrm{O}_{2}$ was detected in leaf discs or tubers slices by incubating tissue samples in a buffer solution containing 33'diamino benzidine-4HCl (DAB) (Vallélian-Bindschedler et al., 1998) or in a buffer solution containing 4-chloro-1-naphtol (Dumas et al., 1995). In situ production of $\mathrm{H}_{2} \mathrm{O}_{2}$ is marked by a brownish precipitate (for the DAB staining) or by a dark blue precipitate (for the 4-chloro-1-naphtol staining).

Oxalate oxidase immunoblot detection. SDS-PAGE (made of 13\% (w/v) acrylamide and $0.35 \%(\mathrm{w} / \mathrm{v}) \mathrm{N}, \mathrm{N}$-bis-methylene acrylamide) was performed as described (Sam- 
brook et al., 1989) with equal amounts of protein loaded for each slot (30 $\mu$ g protein). For immunoblot analysis, the proteins were transferred elecrophoretically to BA85-S nitrocellulose (Schleicher and Schuell, Filtration, Bottmingen, Switzerland) after SDS-polyacrylamide gel electrophoresis (PAGE; Sambrook et al., 1989) and the blots were incubated sequentially for $30 \mathrm{~min}$ in $5 \%(\mathrm{w} / \mathrm{v})$ dried-milk powder (Fluka, Fine Chemicals, Basle, Switzerland) in $25 \mathrm{mM}$ Tris buffer $\mathrm{pH} 7.4$ containing $135 \mathrm{mM} \mathrm{NaCl}$ and $3 \mathrm{mM} \mathrm{KCl}$ (TBS, Sambrook et al., 1989), overnight at $4{ }^{\circ} \mathrm{C}$ with primary antibodies, washed and incubated for $2 \mathrm{~h}$ at room temperature with alkaline phosphatase-conjugated secondary goat anti rabbit antibodies diluted 1:3000. Reactions were visualized in $10 \mathrm{mM}$ Tris buffer $\mathrm{pH} 9.5$ containing $100 \mathrm{mM} \mathrm{NaCl}, 5 \mathrm{mM}$ $\mathrm{MgCl}_{2}, 0.33 \mathrm{mg} / \mathrm{mL}$ sodium 5-bromo-4-chloro-3-indolyl-phosphate (Eurobio, Raunheim, Germany) dissolved in water and $0.66 \mathrm{mg} / \mathrm{mL} 4$-nitroblue tetrazolium chloride (Fluka) dissolved in $70 \%$ dimethylformamide. Anti barley oxalate oxidase antibodies (a kind gift from Rustica Prograin Génétique, Toulouse, France) were diluted at $1: 4000$.

Pathogen inoculation. Inoculation with $P$. infestans (field isolate 94-28, from the Station fédérale de Changins (RAC), Switzerland) was performed by deposition of 4 drops per leaf ( $5 \mu \mathrm{L} /$ drop; 3 leaves/plant) of a spore suspension $\left(5 \mathrm{H} 10^{4}\right.$ spores $/ \mathrm{mL}$ ). Plants were kept at high humidity in the dark at $17^{\circ} \mathrm{C}$ for $24 \mathrm{~h}$, and then placed for 4 $\mathrm{d}$ at $19^{\circ} \mathrm{C}$ in a $16 \mathrm{~h}$ light regime. The sporulation of the pathogen was induced by a treatment of $48 \mathrm{~h}$ at $100 \% \mathrm{RH}$. Disease symptoms were determined by counting the number of lesions per plant. The extent of sporulation was determined by counting sporangia on inoculated leaves. For this purpose, leaves were removed, shaken at 250 rpm for $45 \mathrm{~min}$ in $10 \%$ ethanol and the number of spores was determined in this solution. Inoculation of tubers from wild type and transgenic plants with $E$. carotovora was performed as described by Wu et al. (1995). Briefly, potato tubers were sliced into discs, and each disc was inoculated with $15 \mu \mathrm{L}$ of a bacterial suspension $\left(2 \times 10^{7}\right.$ $\mathrm{cfu} / \mathrm{mL}$ ). Three day after inoculation, the extent of maceration was evaluated by weighing the tubers before and after removing the rotted tissue. The bacterial titers were determined in a suspension of the macerated or control tissue in sterile water; dilutions of this suspension were plated on LB agar plates. Inoculation of tubers from wild type and transgenic plants with $S$. reticuliscabiei (strain CFBP 4531) was performed as described (Bouchek-Mechiche et al., 2000). Bacteria were obtained from the Institut National de Recherches Agronomiques (INRA, F-35653 Le Rheu, France). They were grown at $27^{\circ} \mathrm{C}$ for $10 \mathrm{~d}$ in petri dishes $(90 \mathrm{~mm}$ diameter) on potato dextrose agar. The bacteria were scraped off from three petri dishes and thoroughly mixed with $200 \mathrm{~mL}$ sterile water. This solution was added to the soil of 5 pots $(1.7 \mathrm{~L})$ in which healthy potato tubers were sown (for each line 2 tubers/pot). Plants were grown as described above for a period of two months. After harvest, tubers from each pot were washed and scored for the number of common scab lesions on each tuber.

Experiments were all repeated at least three times; one representative experiment is presented. 


\section{StWT}

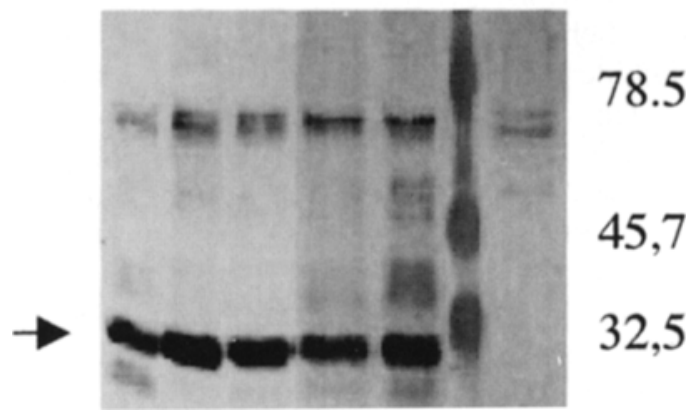

Fig. 1. Western blot analysis of leaves of transgenic potato lines expressing a 35 S-oxalate oxidase gene construct. Leaves from plants 6 week after transfer from in vitro culture were analysed. Arrow indicates position of oxalate oxidase. WT: wild type plants; St: molecular weight standards.

\section{Results}

Leaves and tubers slices of transgenic lines were used to determine the accumulation of $\mathrm{H}_{2} \mathrm{O}_{2}$ compared to untransformed plants. Histochemical staining based on 4chloro-1-naphtol indicated a strong accumulation of a dark blue pigment that is indicative of $\mathrm{H}_{2} \mathrm{O}_{2}$ accumulation in the tissue (data not shown). Comparisons between transgenic lines did not reveal a strong correlation between the accumulation of $\mathrm{H}_{2} \mathrm{O}_{2}$ and exogenous protein as estimated from immunoblots (data not shown). Fig. 1 shows an immunoblot analysis of oxalate oxidase in the leaves of transgenic lines $35 \mathrm{~S}$-oxox 10, 35S-oxox 11, 35S-oxox 12, 35S-oxox 20 and 35S-oxox 22 compared to an untransformed plant. Every transgenic line showed an increased $\mathrm{H}_{2} \mathrm{O}_{2}$ content compared to untransformed control plants. Table 1 shows results from the tests of re-

Table 1. Number of lesions and number of spores in leaves of transformed and untransformed potato lines 1 week after inoculation with $P$. infestans. For each line, twelve plants $(6$ weeks after transfer from in vitro culture) were inoculated on 3 leaves/plant with $5 \mathrm{~mL}$ droplets (4 drops/leaf) of a spore suspension of $P$. infestans $\left(5 \times 10^{4} \mathrm{sp} / \mathrm{mL}\right)$ (means $\pm \mathrm{SE}$; Fisher's protected LSD test; significance level: 0.05 ).

\begin{tabular}{lrl}
\hline Line & Number of lesions & Number of spores $\times 10^{5}$ \\
35S-oxox 10 & $10.1 \mathrm{~d} \pm 1.2$ & $0.92 \mathrm{~d} \pm 0.23$ \\
35S-oxox 11 & $9.4 \mathrm{~d} \pm 3.0$ & $1.56 \mathrm{~d} \pm 0.48$ \\
35S-oxox 12 & $6.0 \mathrm{c} \pm 2.2$ & $0.72 \mathrm{bc} \pm 0.39$ \\
35S-oxox 20 & $6.8 \mathrm{c} \pm 1.9$ & $0.60 \mathrm{c} \pm 0.15$ \\
35S-oxox 22 & $7.5 \mathrm{c} \pm 2.8$ & $0.67 \mathrm{c} \pm 0.27$ \\
Bintje & $10.7 \mathrm{~d} \pm 0.9$ & $1.71 \mathrm{~d} \pm 0.30$ \\
Charlotte & $4.0 \mathrm{~b} \pm 1.5$ & $0.62 \mathrm{~b} \pm 0.2$ \\
Matilda & $2.1 \mathrm{a} \pm 1.4$ & $0.04 \mathrm{a} \pm 0.01$
\end{tabular}


Bintje
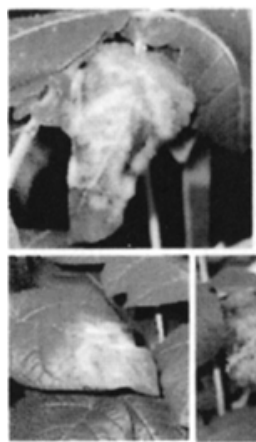

oxox 10
Charlotte
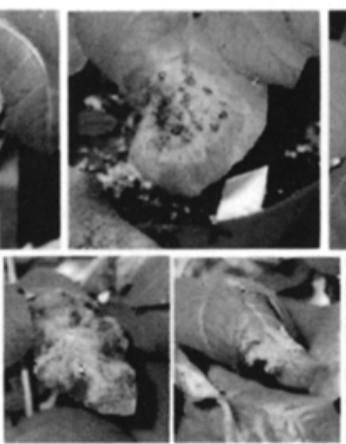

oxox 11

oxox 12
Matilda

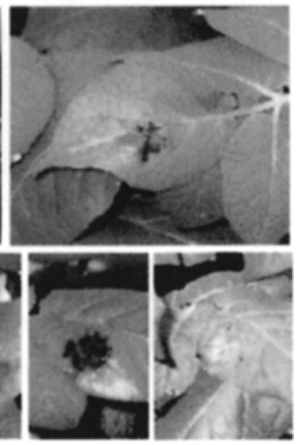

oxox $20 \quad$ oxox 22

Fig. 2. Typical symptoms observed in transgenic potato lines expressing a 35 S-oxalate oxidase gene, 1 week after inoculation of the leaves with $P$. infestans spores ( 4 drops/leaf; 5 $\mu \mathrm{L} /$ drop; $5 \times 10^{4} \mathrm{sp} / \mathrm{mL}$ ).

sistance to $P$. infestans. Lines 35 S-oxox 10 and 11 showed no increase in resistance as assessed by the number of lesions or by the intensity of sporulation. Lines $35 \mathrm{~S}$ oxox 12, 35S-oxox 20 and 35S-oxox 22, showed an increase in resistance compared to cultivar Bintje. This increased resistance was comparable to the resistance of $\mathrm{cv}$. Charlotte. This experiment has been repeated three times with some variations in the intensity of the infection, but the results obtained were comparable. As shown in Table 1, there is a good overall correspondence between the intensity of sporulation and the number of necrotic lesions among all plants. Fig. 2 presents the symptoms observed after inoculation with $P$. infestans. Cv. Matilda shows the formation of a dark necrotic lesion without further spreading of the disease, while the fully susceptible cv. Bintje exhibits typical late blight disease symptoms. Cv. Charlotte presents an intermediate phenotype. The clones 35S-oxox 12, 35S-oxox 20 and 35S-oxox 22 show intermediate symptoms that resemble those observed in cv. Charlotte. Microscopic observation of trypan-blue-stained leaf tissues showed a reduced growth of $P$. infestans mycelia in leaf tissues of lines 35S-oxox 12, 35S-oxox 20, 35S-oxox 22 compared to cv. Bintje (data not shown). Symptoms observed in line 35S-oxox 10 and 11 are similar to those in the susceptible cv. Bintje.

Tubers of the same lines were also tested against the bacterial pathogen $E$. carotovora, but no increase in resistance could be observed (data not shown).

Tubers of cv. Bintje and transformants 35S-oxox 10, 35S-oxox 12 and 35S-oxox 20 and 35 S-oxox 22 were tested for their resistance against $S$. reticuliscabiei, a Gram-positive filamentous bacterium that causes common scab found on potato and other root crops like beet, carrot and radish (Goto, 1992). The number of typical necroses caused by $S$. scabies were significantly reduced in lines $35 \mathrm{~S}$-oxox $10,35 \mathrm{~S}$ oxox 12 and 35S-oxox 22, while line 35S-oxox 20 had an intermediate phenotype 
(Table 2). As shown in Fig. 3, the transgenic lines showed a tuber surface mostly devoid of scab symptoms as compared to cv. Bintje, which is susceptible to this disease.

\section{Discussion}

The present study shows that transgenic plants overproducing an oxalate oxidase from wheat can exhibit improved resistance to an oomycete and a bacterial potato pathogen. Resistance to $P$. infestans was apparent in lines $35 \mathrm{~S}$-oxox $12,35 \mathrm{~S}$-oxox 20 , $35 \mathrm{~S}$-oxox 22 as a decreased sporulation rate indicating an interference on the life cycle of the pathogen. The same lines also exhibited decreased lesion size associated with reduced mycelial growth. The lesion appearance in these transgenic lines was similar to that of the resistant cultivar Charlotte. These results are in agreement with those obtained by $\mathrm{Wu}$ et al. (1995) with transgenic potato overexpressing glucose oxidase, an enzyme that catalyses the conversion of glucose to $\mathrm{H}_{2} \mathrm{O}_{2}$ and gluconic acid. Taken together, these data suggest that $\mathrm{H}_{2} \mathrm{O}_{2}$ production mediates resistance to P. infestans.

Interestingly, no resistance was observed against $E$. carotovora in transgenic plants overexpressing oxalate oxidase. This is in contrast with the results of Wu et al. (1995) who observed a strong protection to E. carotovora. However, results presented by Miguel et al. (2000) show that $\mathrm{H}_{2} \mathrm{O}_{2}$ produced by the plant has no direct antimicrobial effect on the growth of Erwinia chrysanthemi in the plant. It cannot be ruled out that the inhibitory effect observed by Wu et al. on E. carotovora might not have been caused by $\mathrm{H}_{2} \mathrm{O}_{2}$ but by an excessive accumulation of glucuronic acid. More work is needed to understand this apparent discrepancy. The effect of transgenic production of $\mathrm{H}_{2} \mathrm{O}_{2}$ on $\mathrm{S}$. reticuliscabiei was unexpected. So far, this relevant storage disease can be controlled using chemicals (e.g. iron sulfate) or by relevant phytosanitary measures, and in some cases by biocontrol agents. Our results show a better protection of transgenic potato expressing oxalate oxidase against $S$. reticuliscabiei than $P$. infestans. A comparison of $\mathrm{H}_{2} \mathrm{O}_{2}$ produced in tuber tissue using histochemical staining did not show any difference with that observed in leaf discs. Thus

Table 2. Number of lesions/tuber in tubers of transformed and untransformed potato lines after inoculation with Streptomyces reticuliscabiei. After transfer from in vitro culture, 2 plants/line were grown for 2 months in a pot containing soil inoculated with a bacterial suspension of $S$. reticuliscabiei. Tubers were then harvested from each pot and the number of lesions was determined (means $\pm \mathrm{SE}$; Mann-Whitney U-test; the test was carried between Bintje and all transgenic lines; $\mathrm{P}=0.05$ ).

\begin{tabular}{lcl}
\hline Line & Number of lesions/tuber & Number of tubers measured \\
35S-oxox 10 & $0.60 \mathrm{a} \pm 1.34$ & 5 \\
35S-oxox 12 & $0.00 \mathrm{a} \pm 0.00$ & 5 \\
35S-oxox 20 & $9.60 \mathrm{a} \pm 1.60$ & 5 \\
35S-oxox 22 & $3.40 \mathrm{a} \pm 3.78$ & 8 \\
Bintje & $14.00 \mathrm{~b} \pm 0.90$ & 5 \\
\hline
\end{tabular}




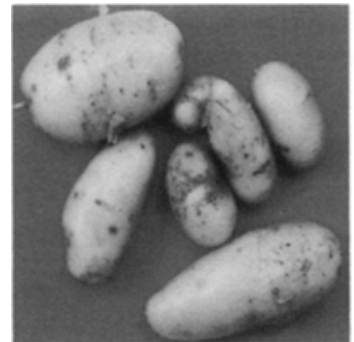

Bintje

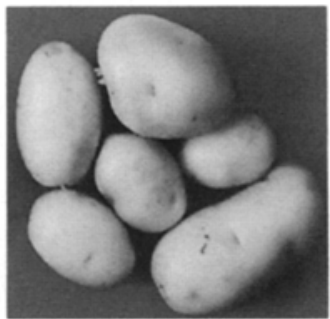

$35 \mathrm{~S}$ oxox20

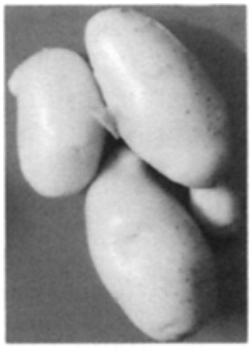

$35 \mathrm{~S}$ oxox10

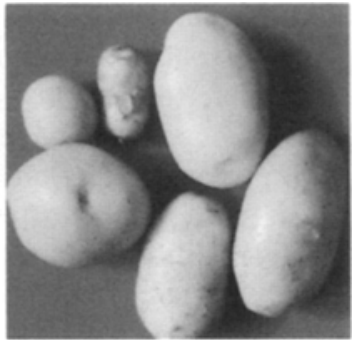

$35 \mathrm{~S}$ oxox12

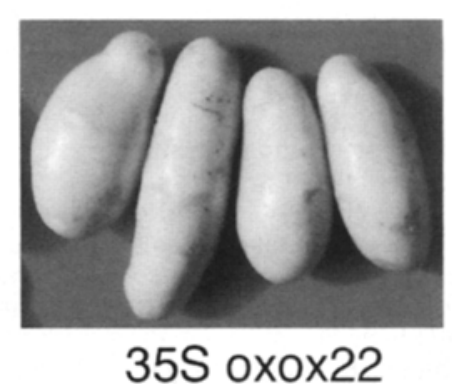

Fig. 3. Typical symptoms observed in tubers of transgenic potato lines expressing a $35 S$-oxalate oxidase gene. Plants were grown for 3 months in soil inoculated with S. reticuliscabiei.

the most likely explanation for the better protection observed in tuber might reside in the nature of the plant-pathogen interaction and oxalate oxidase might be more effective against $S$. reticuliscabiei.

The relevance of oxalate as a target for plant protection has also been demonstrated by studies with biocontrol bacteria that were selected for their oxalate-degrading capacity (Ouchi et al., 1983). It was mainly capitalized that removal of the pathogenicity factor oxalate would decrease pathogenic virulence. In the experiments presented here, it is not known if either $P$. infestans or $S$. reticuliscabiei produce oxalate as a pathogenicity factor during the interaction with the plant. The plant might also produce oxalate during the early steps of infection (Smirnoff \& Pallanca, 1996). The mode of action of resistance conditioned by oxalate oxidase remains thus to be determined.

Oxalate oxidases (germins) are involved in defence responses in cereals to invasion by fungal pathogens. Germins have a stable enzymatic activity that is resistant to the action of broad-specificity proteases and constitute interesting genes for plant defence in dicotyledons, where they are not found naturally (Lane, 2002). This approach was recently described for the first time in soybean. Transgenic plants engineered with a constitutively expressed wheat germin displayed resistance to Sclero- 
tinia sclerotiorum (Donaldson et al., 2001). The results presented here broaden this knowledge. We show that constitutive expression of oxalate oxidase in potato improves resistance to an oomycete and a bacterial pathogen, $P$. infestans and $S$. reticuliscabiei. Thus, constitutive expression of oxalate oxidase might provide a valuable strategy for protection to plant pathogens.

\section{Acknowledgements}

Financial support of the SSPP Biotechnology (Module 6) and from grant 3100055662.98 of Swiss National Science Foundation is gratefully acknowledged. Linda Grainger and Fred Tschuy are gratefully thanked for skilful technical assistance.

\section{References}

Barker, H., B. Reavy, K.D. Webster, C.A. Jolly, A. Kumar \& M.A. Mayo, 1993. Relationship between transcript production and virus-resistance in transgenic tobacco expressing the potato leafroll virus coat protein gene. Plant Cell Reports $13: 54-58$.

Barker, H., K.D. Webster, C.A. Jolly, B. Reavy, A. Kumar \& M.A. Mayo, 1994. Enhancement of resistance to potato leafroll virus multiplication in potato by combining the effects of host genes and transgenes. Molecular Plant-Microbe Interactions 7: 528 530 .

Bevan, M., 1984. Binary Agrobacterium vectors for plant transformation. Nucleic Acids Research 12: 8711-8721.

Bouchek-Mechiche, K., C. Pasco, D. Andrivon \& B. Jouan, 2000. Differences in host range, pathogenicity to potato cultivars and response to soil temperature among Streptomyces species causing common and netted scab in France. Plant Pathology 49: 3-10.

Brisson, L.F., R. Tenhaken \& C.J. Lamb, 1994. Function of oxidative cross-linking of cell wall structural proteins in plant disease resistance. Plant Cell 6: 1703-1712.

Coquoz, J.L., A.J. Buchala, P. Meuwly \& J.P. Métraux, 1995. Arachidonic-acid induces local but not systemic synthesis of salicylic-acid and confers systemic resistance in potato plants to Phytophthora infestans and Alternaria solani. Phytopathology 85: 1219-1224.

Donaldson, P.A., T. Anderson, B.G. Lane, A.L. Davidson \& D.H. Simmonds, 2001. Soybean plants expressing an active oligomeric oxalate oxidase from the wheat $\mathrm{gf}-2.8$ (germin) gene are resistant to the oxalate-secreting pathogen Sclerotina sclerotiorum. Physiological and Molecular Plant Pathology 59: 297-307.

Dumas, B., G. Freyssinet \& K.E. Pallett, 1995. Tissue-specific expression of germin-like oxalate oxidase during development and fungal infection of barley seedlings. Plant Physiology 107: 1091-1096.

Dutton, M.V. \& C.S. Evans, 1996. Oxalate production by fungi: Its role in pathogenicity and ecology in the soil environment. Canadian Journal of Microbiology 42: 881-895.

Goto, M., 1992. Fundamentals of bacterial plant pathology. Academic Press.

Kuc, J., 2001. Concepts and direction of induced systemic resistance in plants and its application. European Journal of Plant Pathology 107: 7-12.

Lamb, C.J., J.A. Ryals, E.R. Ward \& R.A. Dixon, 1992. Emerging strategies for enhancing crop resistance to microbial pathogens. Biotechnology 10:1436-1445.

Lane, B.G., 2002. Oxalate, germins, and higher-plant pathogens. IUBMB Life 53: 67-75.

Lane, B.G., A.C. Cuming, J. Fregeau, N.C. Carpita, W.J. Hurkman, F. Bernier, E. Dratewkakos \& T.D. Kennedy, 1992. Germin Isoforms Are Discrete Temporal Markers of Wheat Development - Pseudogermin Is a Uniquely Thermostable Water- Soluble Oligomeric Protein in Ungerminated Embryos and Like Germin in Germinated Embryos, It Is Incorporated into Cell- Walls. European Journal of Biochemistry 209: 961-969.

Lane, B.G., J.M. Dunwell, J.A. Ray, M.R. Schmitt \& A.C. Cuming, 1993. Germin, a protein marker of early plant development, is an oxalate oxidase. Journal of Biological Chemistry 
268: $12239-12242$.

Levine, A., R. Tenhaken, R.A. Dixon \& C.J. Lamb, 1994. $\mathrm{H}_{2} \mathrm{O}_{2}$ from the oxidative burst orchestrates the plant hypersensitive disease resistance response. Cell 79:583-593.

Mehdy, M.C., Y.K. Sharma, K. Sathasivan \& N.W. Bays, 1996. The role of activated oxygen species in plant disease resistance. Physiologia Plantarum 98: 365-374.

Miguel, E., C. Poza-Carrion, E. Lopez-Solanilla, I. Aguilar, A. Llama-Palacios, F. GarciaOlmedo \& P. Rodriguez-Palenzuela, 2000. Evidence against a direct antimicrobial role of $\mathrm{H} 2 \mathrm{O} 2$ in the infection of plants by Erwinia chrysanthemi. Molecular Plant Microbe Interactions 13: 421-429.

Odell, J.T., F. Nagy \& N.H. Chua, 1985. Identification of DNA sequences required for activity of the cauliflower mosaic virus 35S promoter. Nature 313: 810-812.

Oerke, E.C. \& H.W. Dehne, 1997. Global crop production and the efficacy of crop protection - Current situation and future trends. European Journal of Plant Pathology 103: 203-215.

Ooms, G., A. Bakker, L. Molendijk, G.J. Wullems, M.P. Gordon, E.W. Nester \& R.A. Schilperoort, 1982. T-DNA organization in homogeneous and heterogeneous octopinetype crown gall tissues of Nicotiana tabacum. Cell 30: 589-597.

Ouchi, S., H. Toyoda, S. Utsumi , H. Hashimoto \& T. Hadama, 1983. A promising strategy for the control of fungal disease by the use of toxin-degrading microbes. In: A. Graniti (Ed.), Phytotoxins and Plant Pathogenesis. NATO ASI Series, Springer, Heidelberg, pp. 301-315.

Pignard, A., B. Grezes-Besset, R. Grison \& M. Schneider, 1994. Use of a DNA sequence coding for an oxalic acid degrading protein as a selection gene. In: WO 94/13790.

Sambrook, J., E.F. Fritsch \& T. Maniatis, 1989. Molecular cloning: a laboratory manual. Cold Spring Harbor Laboratory Press, Cold Spring Harbor.

Smirnoff, N. \& J.E. Pallanca, 1996. Ascorbate metabolism in relation to oxidative stress. Biochemical Society Transactions 24: 472-478.

Tenhaken, R., A. Levine, L.F. Brisson, R.A. Dixon \& C.J. Lamb, 1995. Function of the oxidative burst in hypersensitive disease resistance. Proceedings of the National Academy of Sciences of the United States of America 92: 4158-4163.

Vallelian-Bindschedler, L., P. Schweizer, E. Mosinger \& J.P. Métraux, 1998. Heat-induced resistance in barley to powdery mildew (Blumeria graminis f.sp. hordei) is associated with a burst of active oxygen species. Physiological and Molecular Plant Pathology 52: $185-199$

Wu, G.S., B.J. Shortt, E.B. Lawrence, J. Leon, K.C. Fitzsimmons, E.B. Levine, I. Raskin \& D.M. Shah, 1997. Activation of host defense mechanisms by elevated production of $\mathrm{H}_{2} \mathrm{O}_{2}$ in transgenic plants. Plant Physiology 115: 427-435.

Wu, G.S., B.J. Shortt, E.B. Lawrence, E.B. Levine, K.C. Fitzsimmons \& D.M. Shah, 1995. Disease resistance conferred by expression of a gene encoding $\mathrm{H}_{2} \mathrm{O}_{2}$-generating glucose oxidase in transgenic potato plants. Plant Cell 7: 1357-1368. 